\title{
A festa do Divino Espírito Santo em Santa Cruz de Goiás. Um universo rico de manifestações culturais
}

institucional.us.es/ambitos/

\section{Liberalina Teodoro de Rezende}

Universidade Estadual de Goiás

libeteodoro@gmail.com

\author{
Sandro Dutra e Silva \\ Centro Universitário de Anápolis (Universidade Estadual de Goiás) \\ sandrodutr@hotmail.com
}

\section{Giovana Galvão Tavares}

Centro Universitário de Anápolis (UniEvangelica)

gio.tavares@gmail.com

\section{Maria Idelma Vieira D'abadia \\ Universidade Estadual de Goiás \\ midabadia@bol.com.br}

\section{Abadia de Lourdes da Cunha \\ Centro Universitário de Anápolis (UniEvangelica) \\ bacunha6@hotmail.com}

English Version: The feast of the Holy Spirit of Santa Cruz de Goiás. A rich universe of cultural events

\begin{abstract}
Resumo
Este trabalho visa analisar o patrimônio cultural imaterial da cidade de Santa Cruz de

Goiás, Centro-Oeste brasileiro, por meio da reflexão quanto às práticas sociais vivenciadas pelos membros dessa comunidade durante as celebrações das festividades do Divino Espírito Santo. Buscamos nos fundamentar nos pressupostos teórico-metodológicos da História Cultural, na medida em que nos possibilita

descrever como vivências cotidianas aliadas a sensibilidades das manifestações populares tradicionais. Utilizamos, ainda, a técnica de pesquisa qualitativa do Grupo

Focal e da Observação Participante para ampliar informações, conhecer e compreender atitudes, percepções, opiniões e comportamentos relativos aos
\end{abstract}

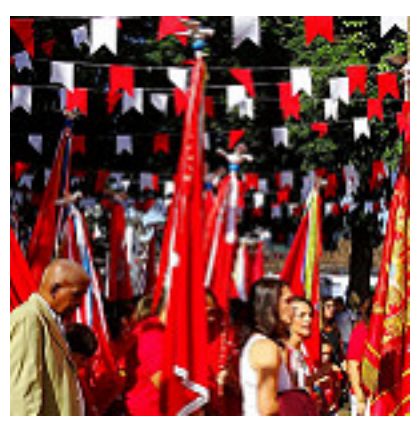

festejos do Divino Espírito Santo de Santa Cruz.

\section{Palavras-Chave}

História Cultural, Festejos do Divino, Patrimônio Cultural Imaterial, Tradição e Devoção Popular.

Abstract

This study aims to analyze the intangible cultural heritage of the city of Santa Cruz de Goiás, Brazilian Midwest, through reflection about the social practices experienced by members of the community during the celebrations of the festivities of the Holy Spirit. We seek to support the theoretical and methodological assumptions of Cultural

History, in that it enables us to describe how everyday experiences combined with sensitivities of traditional demonstrations. We use also the qualitative research technique of focus groups and participant observation to enlarge information, know and understand attitudes, perceptions, opinions and behaviors related to these celebration. 


\section{INTRODUÇÃO}

Esse artigo tem como objetivo o estudo das festividades do Divino Espírito Santo em Santa Cruz de Goiás. Essas festividades ocorrem desde o período colonial brasileiro, cujos registros apontam o início nas primeiras décadas do século XIX, compondo um rico universo de manifestações culturais. É uma festividade de caráter popular e que preserva um estilo religioso dos festejos aos santos (missas, novenas e celebrações) e as tradições que envolvem os festejos de abordagem folclórica (Folia do Divino, o Batuque, a Contradança e a Cavalhada).

As potencialidades culturais envolvidas nesses festejos podem ser evidenciadas, por meio de um olhar sem muita pretensão, nos vestígios do patrimônio cultural imaterial, na devoção de seu povo e nas tradições. A cultura tradicional e suas manifestações culturais vêm sendo estudadas com produções científicas que versam na área do patrimônio imaterial, particularmente na questão da religiosidade popular e do folclore. O meio acadêmico busca legitimar o que é verdadeiro na visão popular e desvelar novos horizontes para uma nova realidade de estudos nesta área.

A Festa do Divino Espírito Santo de Santa Cruz de Goiás, é uma festa com rituais religiosos e com uma gama bastante numerosas de atividades folclóricas que se misturaram com as religiosas e hoje se fazem mescladas, de modo que, torna-se difícil muitas vezes, distingui-las e separá-las. Os festejos em Santa Cruz mantêm as características de seu traçado original, na sua arquitetura setecentista, oferecendo aos turistas que a visitam, um encontro com a história colonial.

No aspecto religioso e, em consonância com os registros históricos, observamos que a popularização dos festejos do Divino Espírito Santo que se insere como ritual católico com detalhes do sincretismo que marcam as tradições coloniais no Brasil. As danças pagãs se tornaram sagradas e se agregaram de forma sincrética aos festejos e comemorações.

A metodologia adotada para alcançar os objetivos propostos, insere-se no campo da historiografia cultural. Com suporte nesses pressupostos da história Cultural o estudo focou o olhar sobre as práticas estabelecidas na Festa do Divino de Santa Cruz de Goiás, por meio de suas características culturais, imbricadas neste contexto de hábitos e costumes singularmente arraigados nesta comunidade.

Nessa proposta de investigação foram utilizados dois procedimentos metodológicos centrais para a realização da pesquisa, a saber: a Observação participante e o Grupo Focal. Primeiramente realizamos a Observação Participante que buscou no período da preparação e da realização dos festejos, coletar dados e informações, sistematiza-los e analisá-los para construir conhecimento específico sobre a temática investigada. Desse modo, a realização de pesquisas com a metodologia da Observação Participante, implica um tempo extenso de observação do objeto a ser pesquisado. Privilegiamos uma postura em que o distanciamento/aproximados dos pesquisadores envolvidos e o objeto de investigação pautada na disciplina, alteridade e pertinência científica.

Também foram realizados trabalhos investigativos com os grupos focais estruturados. Para tanto, foram feitas reuniões em local específico, contanto com um público diverso, que indicava um universo variado de representação nas festividades (foliões, gestores, coordenadores de atividades, clero, políticos, dentre outros). Essas reuniões ocorreram no período que antecedeu os festejos, nos meses de abril e maio. A técnica do Grupo Focal é de levantamento de dados, permite capturar expressões, linguagens e comentários diversos. Apresenta uma influência mútua entre os participantes, em que cada um se sente à vontade para falar ou comentar a fala alheia.

As características do Grupo Focal viabilizaram a compreensão das diversas percepções do grupo. As atitudes das pessoas em determinados momentos, as participações culturais, seus anseios, medos, receios, são facilmente percebidos nesses momentos.

Por últimos, realizamos o Grupo Focal "Itinerante", com o propósito de analisar de forma minuciosa cada evento. O Grupo Focal "Itinerante" é uma criação espontânea nossa. Foi realizado nos momentos dos ensaios para a realização dos diversos eventos que estão inseridos nos festejos do Divino, e nas realizações desses eventos folclóricos. Em determinados momentos, reuníamos com os participantes e realizávamos o Grupo 
Focal Itinerante, quase sempre em movimento. Nos momentos de atividades, em que os atores e os espectadores estavam envolvidos com os festejos, ora atarantados pela correria das organizações, ora assistindo às apresentações. Isso possibilitou-nos um acervo riquíssimo de informações. O trabalho com os Grupos Focais Itinerantes abriu um leque de possibilidades de coleta de dados para a nossa pesquisa. Os pesquisadores se inseriram como integrantes desses festejos, desenvolvendo conservas, observações, anotações no transcorrer dos festejos. O olhar investigativo e a atenção aos detalhes permitiaram a coleta de informações preciosas. Momentos riquíssimos de observação e análise de tudo à nossa volta. Esse trabalho itinerante foi realizado durante os festejos da Folia do Divino, da Contradança, do Batuque, da Cavalhada, nos folia do coronel, com os jovens, com as mulheres envolvidas nos preparativos da festa e com os participantes.

A pesquisa contou com o trabalho interdisciplinar da linha de pesquisa "Sociedade e Meio Ambiente" do Programa de Pós-Graduação em Sociedade, Tecnologia e Meio Ambiente da UniEVANGELICA, em parceria com o Programa de Pós-Graduação em Territórios e Expressões Culturais do Cerrado da Universidade Estadual de Goiás.

A História Cultural permite uma ampla visão do processo histórico, não se limitando apenas aso estudos da produção cultural propriamente dita, mas, tem a proposta de realizar estudos amplos envolvendo os determinados grupos sociais. Desse modo, trabalhar com esse método, permite nos colocarmos como "investigadores", em busca de desvendar um enigma na coleta de dados que vão aos poucos desvelando sentidos (Ginzburg, 1991). O desafio se faz por meio de um olhar investigativo ao passado e no trabalho com as fontes e os "indícios" disponíveis (crônicas de viajantes, observação de memorialistas e folcloristas, imprensa leiga e religiosa, iconografia, tradição oral), e outros mais que nos possibilitam investigar parte do patrimônio cultural desta localidade.

De acordo com Dias (2006), o patrimônio cultural é uma construção social e cultural, estabelecido pela vivência de uma comunidade, de um povo, uma nação. Numa legitimação cultural e "simbólica social" que configura os objetos, valores, na produção coletiva de identidade, de sentimento numa representação simbólica, onde reconhece os símbolos como sendo os transmissores da cultura mantendo o link do homem com um passado ligado às necessidades do presente.

O patrimônio cultural segundo Bourdieu (2001) pode ser identificado como manifestação do "capital cultural" socialmente reproduzido por meio de um processo que recria de modo permanente numa interação com o meio ambiente que Ihe é peculiar, num fazer histórico relacionado à natureza e também com a cultura, formando desse modo, indenitários sentimentos e se faz por uma construção material e imaterial.

A fundação deste município teve a sua origem na expansão das fronteiras da mineração no Brasil Colonial, sendo considerado um dos primeiros povoados do Estado de Goiás. A mineração se fez como marcante para o povoamento do Centro-Oeste brasileiro no século XVIII. Fizeram parte deste cenário, aventureiros, índios, escravos e garimpeiros. No século XIX, com a esgotamento da mineração, a atividade da pecuária foi a alternativa econômica encontrada. No século XX, após a chegada dos trilhos da estrada de ferro na região, Santa Cruz de Goiás passou a receber camponeses que intensificaram a atividade agrícola.

As manifestações culturais em Santa Cruz têm origens deste o período colonial no século XVIII, integrando a comunidade em festividades de origem religiosa católica, como a Festa do Divino Espírito Santo, Nossa Senhora do Rosário, São Benedito, São Sebastião e Nossa Senhora da Conceição que é a padroeira da cidade. Tem os festejos juninos em homenagem a São Pedro e Santo Antônio e São João e outras manifestações culturais que acontecem ao longo do ano.

\section{TRADIÇÃO E DEVOÇÃO NOS FESTEJOS DO DIVINO ESPÍRITO SANTO}

A Festa do Divino Espírito Santo tem origem europeia, do período medievo, e considerada uma das realizações festivas mais antigas do povo brasileiro. Sua celebração inicia-se a cinquenta dias após o domingo de páscoa, é considerada uma festa móvel, de acordo com o calendário católico, sendo uma homenagem à descida do Divino Espírito Santo sobre os doze apóstolos de Jesus. Em Portugal era prática a celebração de festas 
católicas e esses rituais foram levados para suas colônias. Os portugueses festejavam até mesmo nas embarcações marítimas que os transportavam às suas regiões coloniais (Silva, 2002).

O ritual do Divino com a coroação do Imperador e outras celebrações também foram práticas dos portugueses em plenas embarcações. Assim, os portugueses trazem consigo suas principais tradições festivas para sua colônia brasileira, permanecendo por um determinado tempo de consonância com os seus costumes. Mais tarde elas vão sendo reelaboradas e ganham contornos brasileiros (Bonetti, 2004).

Dada a origem portuguesa desta festa, no Brasil também tem por prática a coroação do Imperador durante os festejos do Divino com algumas nuancem de diversidades comemorativas de região para região. Em Goiás não é diferente, várias localidades festejam o Divino e ocorrem de várias formas tais como: folias, congadas, contradança, novenas, procissões, cavalhadas, foguetório e banquetes com as mais variadas comidas, doces, quitutes, quitandas, jantares e outros mais.

Em Goiás existem diversas localidades onde acontece a Folia do Divino. Porém as primeiras notícias desta Folia do Divino em Goiás são do início do século XIX, nos registros do naturalista francês Saint-Hilaire, conforme indicação abaixo:

Em julho de 1819, ao voltar de Goiás para São Paulo, passando por Meia Ponte, ele atravessou a floresta chamada "Mato Grosso de Goiás" e, encontrou homens a cavalo, um deles com uma bandeira, outro com um violão e outro com um tambor, os quais levavam burros carregados de provisões. Era a folia do Divino que saia de Curralinho a arrecadar donativos para a festa a se realizar em agosto. (Silva, 2002, p. 57).

Em Goiás os festejos da folia têm em comum os mesmos rituais que a tradição colonial perpetuou, ou seja, coletar donativos entre os moradores da comunidade, propor encontros de socialização da devoção nos momentos de confraternização, como também prestar homenagem ao e festejar, em adoração comunitária o Divino Espírito Santo. O que diferencia umas das outras, são os momentos da folia depois do ritual sagrado, que são as brincadeiras dos foliões, as danças e outros tipos de confraternização em formado de festejos não religiosos. As mais conhecidas são o "Catira e o Xá", em outras são os forrós ou bailes da roça (Bonetti, 2004). No início do século XX em Goiás a igreja proibiu essa folia como as outras (de Reis, de são Sebastião, de São Benedito, e outras), numa tentativa de coibir os abusos do uso do álcool e outros excessos. Mas, nem isso as extinguiu, essa tradição persiste tanto no campo como nas cidades e continuam vivas mediante a cultura secular passada de geração a geração.

Os rituais dos festejos do Divino iniciam com a organização das residências que receberão a visita da Bandeira do Divino, "[...] a trinta e três residências, em homenagem aos trinta e três anos que Nosso Senhor Jesus Cristo viveu na Terra." (Alves, 1983, p. 42). Ainda hoje essas visitas acontecem, são chamadas de Folia do Divino. Em cada residência visitada, são realizados cânticos e orações e uma refeição farta, seja café da manhã, almoço, ou lanche da tarde e hoje não visitam tão somente 33 lares, mas tantos quantos os convidam ou o grupo dê conta de visita-los.

Um ritual que tem por iniciativa a programação realizada por pessoas da cidade que visa estender as cerimônias religiosas da Festa do Divino à toda comunidade urbana e rural, bem como em municípios circunvizinhos que vão sendo envolvidos pelos cantos e rituais da folia do Divino tanto no campo religioso quanto no sentido do profano que são mesclados nos movimentos e nas ações de cada folião.

Os foliões se põem a caminho, pequeno cortejo de instrumentalistas e cantores, primeiro percorrem as fazendas que foram anteriormente escolhidas para essa visita, procurando pontos estratégicos das diversas regiões do município de modo que, ao visitar uma fazenda ali ocorre o encontro de uma comunidade religiosa do meio rural ou que possa ao oferecer estrutura a receber os diversos fiéis da região em um só momento.

Para Fátima Paraguassú e Curado em se falando de folia em Santa Cruz: "[...] para alguns, é apenas divertimento, farra, bebedeira, algazarra, não passa de expressão caipira e inculta. [...] é devoção; carrega o espírito religioso; evidencia uma situação bem interessante, na aglomeração de adeptos e devotos [...]" (2014, p. 144). Antes essas fazendas visitadas ofereciam pouso aos foliões que geralmente faziam esse percurso à cavalo ou mesmo à pé, hoje não mais assim, a prefeitura municipal através a Secretaria de Cultura oferece 
ônibus que transportam os foliões que vão e retornam todo final de tarde de suas andanças. De acordo com Brandão, reportando às folias rurais, afirma que nelas:

[...] foliões cavaleiros foram grandes e muito solenes no passado, e ainda hoje mantém a mesma estrutura ritual para pedir ofertas ao Divino nas chácaras, sítios e fazendas da redondeza: deslocam-se pedem esmola e agradecem, cerimônia que realizam levando uma das bandeiras do Divino. Eles costumam pedir pousada nos lugares mais distantes, rezar terços e mesmo realizar bailes "dominados por catiras nos locais onde a folia pousa" (Brandão, 1976: 35).

Em Santa Cruz a folia do Divino é realizada por um grupo de foliões somente. Os primeiros giros ocorrem no distrito de Santo Antônio do Rio do peixe e por cidades vizinhas. Nos últimos dias que antecedem a Festa os foliões percorrem a cidade, procurando visitar a maior quantidade de famílias de modo que, tanto no campo como na cidade e na região mais próxima todos recebem o anúncio da Festa do Divino e nessa ocasião do giro da folia do Divino, vão angariando donativos para a realização da festa. No período do giro da folia, a Bandeira do Divino é carregada por dois alferes, e vão percorrendo as diversas fazendas, e casas de famílias dos fiéis e nesses lugares de "petitórios", os foliões são sempre recebidos com muita emoção.

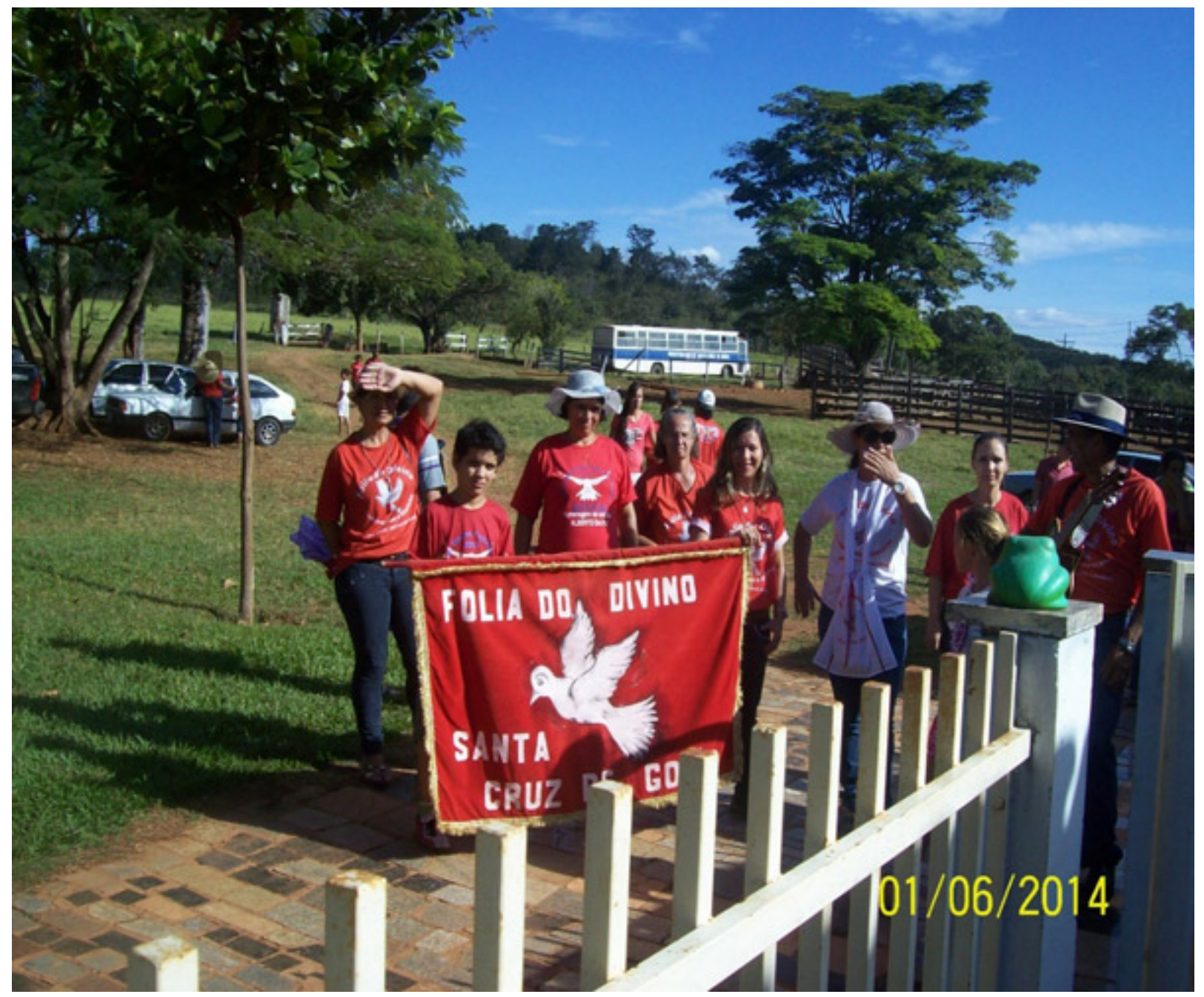

Figura 01: Chegada da Bandeira do Divino na zona rural de Santa Cruz de Goiás.

Fonte: Liberalina Teodoro de Rezende, Santa Cruz de Goiás, Junho/2014

A figura 1 evidencia a chegada da folia do Divino numa fazenda do município, no dia 01 de junho de 2014. Podemos observar que a Bandeira chega à frente com a imagem da representação do Espírito Santo. Ao fundo o ônibus da prefeitura municipal que faz essa parceria com os foliões e os levam em todas as visitas do Divino no meio rural. Pode ainda observar uma foliã vestida de branco com uma sacola colocada no pescoço, é esta foliã (tesoureira da folia) a responsável para receber e guardar os donativos doados pelas famílias visitadas tanto no meio rural quanto na cidade. Esta foliã é a responsável para a prestação de contas dos donativos angariados, e em cerimônia coletiva na Paróquia de Santa devolve as oferendas ao pároco. Na realidade, em cada casa visitada, sempre ganham donativos para a festa, afinal como dizem na região: "ninguém é tão 
necessitado que não possa oferecer algo ao Divino pois todos se sentem devedores pelos vários benefícios recebidos durante o ano todo" (Grupo Focal) Nessas andanças, a Folia vai de porta em porta, no campo, na cidade, em seu derredor, ao som das músicas entoadas pelos foliões, recolhendo donativos. A falar da chegada da Festa, a acolhida é sempre com alegria, emoção. O cafezinho, as esmolas, tudo se pede cantando e louvando ao Divino Espírito Santo.

"Além da esmola e dos versos inspirados na história bíblica do nascimento de Jesus, os foliões, guiados pela embaixatriz Paula Cristina que herdara de seu falecido pai a arte do improviso lança mão de uma criatividade ímpar: improvisam na cantoria das tristezas, dificuldades, alegrias, conquistas, saudades..." (Paraguassú e Curado, 2014: 145).

São cantigas para cada momento, cada situação é muito carregada de simbolismo que envolve o universo folclórico e tradicional desta festa. Ao acompanhar vários dias com esta folia, tanto pela observação participante quanto pelo grupo focal itinerante, percebemos que esse é um ritual em que os foliões se entregam, sem correrias, sem cansaço. Tanto nas fazendas como nas cidades, os foliões se colocam dispostos, organizando a sua agenda de trabalho para liberação nos dias da folia. Por isso, percebemos que existe um clima de devoção e celebração coletiva, tanto por parte dos foliões quanto pelas pessoas que recebem o cortejo em suas residências.

Durante a pesquisa pudemos registrar, também, a musicalidade que faz parte do ritual e da tradição da folia. Nós destacamos, dentre as músicas entoadas nos cortejos rurais o "Canto da entrada da Bandeira do Divino", que é um canto de prelúdio e de introdução do cortejo na residência que irá receber os foliões. Esse momento é feito como muita devoção, considerando o ato de louvor e rendição de graças, pela casa que abre às portas aos foliões e à Bandeira, pelas doações, e ao mesmo tempo esses momentos são oportunos para preces, súplicas e bênçãos por parte do público presente. Nas tradições rurais, esse momento era também de gratidão pela colheita agrícola, pelo sustento e por preces para as bem-aventuranças no plantio e nas próximas colheitas. Esse sentido parece se repetir, mas com outros sentidos, muito menos ligados à tradição camponesa, apesar de acontecerem nos espaços rurais.

Atualmente, as famílias se dividem entre o campo e a cidade no que se refere aos rendimentos financeiros e o sustento da casa. Mas, de certa forma, o sentido da devoção, entre súplica e gratidão são perceptíveis nos gestos, nas falas e nas manifestações de confraternização coletiva. O Canto de Entrada traz referências do universo rural, envolvendo o plantio e a colheita, sob as bênçãos do Divino Espírito Santo, quando entoam: "A bandeira acredita, que a semente seja tanta, que essa mesa seja farta, que essa casa seja santa, ai, ai" (domínio público). Este trecho evidencia a sacralidade da folia do Divino, a devoção dos foliões na crença e no rogo pela abundância da colheita. Essa expressão cultural, típica do mundo rural, manifesta as crenças de que a repetição da folia é uma forma de homenagear o santo devoto e ao mesmo tempo rogar pela permanência da chuva, da fertilidade do solo e pela farta colheita.

A musicalidade também faz referências a outros episódios bíblicos, como no trecho do mesmo canto: "Como os três Reis magos, que seguiram a estrela guia, a bandeira segue em frente, atrás de melhores dias, ai, ai. No estandarte vai escrito, que ele voltará. Que o Rei será bendito, ele nascerá do povo, ai, ai" (domínio público). Esses versos fazem uma recomendação ao devoto a perpetuar a devoção, até a volta do "Rei bendito". Isso evidencia uma preocupação quanto à manutenção dessas festividades como traços de uma comunidade em fortalecer os laços sociais, em unificar os seus concidadãos no espírito religioso e na devoção.

Além dos festejos na zona rural, ocorrem ainda as comemorações na cidade. Um dos principais momentos dos festejos refere-se ao sorteio do "Imperador", que na prática será o festeiro responsável pela administração da Folia. Esse imperador terá um ano de mandato, e será responsável pela organização do próximo evento. Em Santa Cruz ocorre o sorteio de três festeiros, considerando que acontecem três festejos concomitantemente: A Folia do Divino Espírito Santo, de Nossa Senhora do Rosário e de São Benedito.

Os rituais dos festejos do Divino iniciam com a organização das residências que receberão a visita da imagem do Divino, sendo distribuídas em trinta e três residências. A tradição da festa considera esse número como símbolo da idade de Cristo (Bonetti, 2004). Em cada residência visitada são realizados cânticos e orações e 
uma refeição farta, seja café da manhã, almoço, ou lanche da tarde.

As programações se estendem até os dias em que são realizadas as homenagens aos três santos festejados. As novenas festivas são realizadas por nove dias consecutivos, no primeiro dia começam com a alvorada matinal, momento em que a Banda de Música com seus repiques e muitos fogos acordam a comunidade como a convidá-los para as novenas noturnas.

Nos três últimos dias realizam-se o "Tríduo", que são as novenas realizadas na Igreja, sendo que para cada dia em santo é homenageado. No final de cada celebração e após o hasteamento das Bandeiras dos santos costumam acontecer uma queima de fogos. No final do terceiro dia encerram-se as novenas e iniciam-se as atividades de cunho social e recreativo dos festejos. Realizam-se leilões na praça com a participação de muitos fiéis da zona rural, urbana e de outras cidades circunvizinhas.

No nono dia, após as solenidades religiosas da novena, os fiéis vão à casa do Mordomo (guardador da bandeira do Divino). A bandeira é levada pelas mãos de crianças da comunidade até a frente da igreja, onde ao som das músicas entoadas pela banda e de folgues, assomados de palmas e louvores dos fiéis. Apesar de ser um momento solene pelo cunho religioso, para a comunidade é essa celebração é uma oportunidade de reencontro com os familiares, amigos e visitantes. Dessa forma esses festejos tem um caráter sócio religioso, sendo que a programação e o sustento da festa decorrem do trabalho e das doações dos devotos e da comunidade de Santa Cruz.

A expressão dessa celebração é percebida no movimentar dos fiéis que aglutinam no entorno da igreja, nos momentos de celebrações, é percebida como "[...] força máxima de expressão vivenciada pelos rituais de uma religiosidade popular e de um encontro de lazer, garantindo ao lugar uma característica especial que marca e reproduz a festa [...]" (D’Abadia, 2014: 160).

Num sentido coletivo a festa se relaciona com as pessoas e os lugares onde ela ocorre. Liga-se também aos seus autores, idealizadores e organizadores de modo geral relaciona-se com o povo e inscreve-se numa dinâmica social momentânea. Para Silva (2002), as festividades religiosas no Brasil se caracterizam como uma expressão teatral decorrente da organização social, política, religiosa e simbólica de uma determinada comunidade. A autora ressalta que além do caráter recreativo que os festejos apresentam, eles são a expressão dos vínculos sociais de pertencimento e de generalidade coletiva na reafirmação dos laços de solidariedade.

A folia do Divino segue a tradição de fortalecer os laços sociais na medida em que procura democratizar o percurso dos festejos. Os foliões se põem a caminho, pequeno cortejo de instrumentalistas e cantores. Primeiro percorrem as fazendas que foram anteriormente escolhidas para essa visita, procurando pontos estratégicos das diversas regiões do município de modo que, ao visitar uma fazenda ali ocorre o encontro de uma comunidade religiosa do meio rural ou que possa ao oferecer estrutura a receber os diversos fiéis da região em um só momento.

Antes essas fazendas visitadas ofereciam pouso aos foliões que geralmente faziam esse percurso à cavalo ou mesmo a pé. Atualmente, a Prefeitura Municipal, por meio da Secretaria de Cultura, oferece transporte aos foliões. Eles participam dos cortejos, mas retornam no final do dia para as suas moradias. $O$ antropólogo Carlos Brandão descreve esses cortejos em Goiás da seguinte forma:

"[...] foliões cavaleiros foram grandes e muito solenes no passado, e ainda hoje mantém a mesma estrutura ritual para pedir ofertas ao Divino nas chácaras, sítios e fazendas da redondeza: deslocam-se pedem esmola e agradecem, cerimônia que realizam levando uma das bandeiras do Divino. Eles costumam pedir pousada nos lugares mais distantes, rezar terços e mesmo realizar bailes "dominados por catiras nos locais onde a folia pousa" (Brandão, 1976: 35).

Na região de Santa Cruz essa tradição se mantem. Nos últimos dias dos festejos os foliões percorrem a cidade, procurando visitar a maior quantidade de famílias de modo a atender os moradores do campo e cidade. De forma geral, todos recebem o anúncio da Festa do Divino e nessa ocasião do giro da folia do Divino, vão angariando donativos para a realização dos festejos. 


\section{RESULTADOS}

Em Santa Cruz a folia do Divino é realizada por um grupo de foliões somente. No período do giro da folia, é carregada por dois alferes. A Bandeira do Divino que é de cor vermelha com a imagem de um pombo branco representando o Espirito Santo. Existem cantigas tradicionais que são entoadas para cada situação e muito carregadas de simbolismo que caracterizam o universo folclórico e tradicional da festa.

Pela pesquisa de observação participante e de Grupo Focal Itinerante observamos que esse é um ritual em que os foliões se entregam, sem correrias e sem cansaço. Tanto nas fazendas como nas cidades, os foliões se colocam com disposição para os longos rituais. É visível a devoção e o envolvimento coletivo, tanto por parte dos foliões quanto pelas pessoas que recebem a folia em suas moradias e também nos visitantes que acompanham.

A pesquisa também identificou que essa tradição, apesar de estar vinculada a uma tradição religiosa tem adesão de diferentes camadas sociais e faixas etárias. A participação de muitos jovens e o envolvimento destes na devoção comunitária nos chamou atenção. O Grupo focal evidenciou que estes têm consciência da preservação do patrimônio imaterial dos festejos e veem nesse ato uma forma de perpetuar as tradições na comunidade.

Tanto com os foliões mais jovens quanto com os mais antigos, a preocupação com a manutenção da ordem e dos rituais de celebrações da folia, seus cantos, a bandeira, o simbolismo e as rezas, são visualizados como patrimônio imaterial e percebe-se uma necessidade de preservação dessa identidade.

As pesquisas também evidenciaram que a comunidade foi adaptando e incorporando atualizações nas celebrações. Isso se fez com a legitimidade da comunidade, mas nem todos concordavam com as alterações. Um exemplo citado pelos envolvidos são as novenas em forma de celebrações aos santos, que antigamente eram realizadas durante nove dias e que atualmente em três dias, os quais denominam de "Tríduo" (Grupo Focal Itinerante, 06/06/2014).

Interessante ressaltar ainda que, nos diversos momentos de organização e realização dos eventos folclóricos, percebemos a presença de crianças e jovens, o que denota um processo sustentável dessa tradição. Uma preservação cultural para as futuras gerações. De acordo com a observação participativa, observamos que a manutenção dessa tradição é de responsabilidade de todos os envolvidos nos festejos do Divino.

Percebemos ainda que essas festas criam fendas de resistências transculturais, em espaços formados por trocas múltiplas de olhares e significados políticos e religiosos que transpunham as barreiras formadas entre o sagrado e o profano, de vez que, nos rituais festivos que eram resquícios da herança portuguesa, os colonos foram criando e recriando sua cultura e suas tradições. Tanto que: "A festa, uma vez começada, transformavase em exutório para suportar as árduas condições de vida das classes subalternas na colônia” (Del Priore, 2000: 90).

Os pesquisados também evidenciaram que atualmente ocorre uma mercantilização dos festejos. Eles citam a adensamento de barracas com venda de produtos comuns de feiras comerciais. Destacam que os festejos tradicionais eram poucas barracas, cobertas de palha de coqueiros, evidenciando a rusticidade sertaneja e com a venda de produtos e comidas típicas da região. Também destacam uma tradição que estão querendo retomar, que é o trajeto dos carros de boi. Os moradores da zona rural vinham nesses carros e ficavam arranchados nos espaços vazios da cidade ou nos quintais das casas de amigos e conhecidos. Atualmente não existe mais essa tradição, mas eles querem retomar, inclusive a juventude. (Grupo Focal Itinerante, 05/06/2014).

De acordo com o Grupo Focal, esses festejos religiosos renovam a devoção comunitária. Para os participantes, as festividades religiosas, tem a sua importância social. No entanto, para esse grupo, o grande elemento motivador está na devoção católica. Consideram que participar dessa tradição restitui a tradição ancestral, de memória, de um renascimento espiritual. Nessa parte, alguns se emocionaram nos depoimentos. Dizem, "é a fé...". Os depoimentos do grupo focal evidenciam que o caráter festivo, que inicialmente pensávamos ser o 
grande motivador da coesão social, são secundários frente à devoção. Alguns afirmaram que essa atividade dava a eles força espiritual para lidar com os desafios que se apresentam no restante do ano. (Grupo Focal Itinerante, 07/06/2014). Constatamos, portanto, conforme observações de Geertz (2001), a presença do elemento simbólico característico do universo da devoção:

A religião, sem interioridade, sem uma sensação "banhada em sentimento" de que a crença importa, e importa tremendamente, de que a fé sustenta, cura, consola, corrige as injustiças, melhora a sorte, garante recompensas, explica, impõe obrigações, abençoa, esclarece, reconcilia, regenera, redime ou salva, mal chega a ser digna desse nome (Geertz, 2001: 159).

Portanto, o caráter social dos festejos é reforçado nos sentidos religiosos que esse festejo tem para os membros dessa comunidade. Momento de sociabilidade, que cria o ambiente necessário para as estabilidades coletivas, criando elos sociais de confiabilidade e continuidade. Os festejos englobam um conjunto de atividades e rituais que se completam uma na outra, em momentos diferentes no decorrer dos cortejos, ensaios, apresentações, procissões, missas, novenas, jantares, cavalhadas, dentre outras. Num mesmo dia os participantes podem acompanhar o Batuque na caminhada da fé pela madrugada, participar da folia do Divino, assistir ao ensaio da Cavalhada e no início da noite participar ou dos festejos do Coronel ou da novena e do leilão da Paróquia (Grupo Focal Itinerante, 05/06/2014).

As pesquisas qualitativas evidenciaram, portanto, o grande envolvimento dos participantes na festividade e na manutenção dessa tradição. Percebemos a grande carga social na demarcação cultural de capitais entre os envolvidos. Nesse sentido, não apenas um envolvimento religioso, que é significativo, mas que também não está isento de outros elementos culturais como o status social dos festeiros organizadores e dos capitais simbólicos a eles agregado.

\section{CONCLUSÕES}

Os festejos do Divino em Santa Cruz aliam a sacralidade em todos os eventos que a eles estão agregados. Mesmo os eventos folclóricos recebem uma conotação do sagrado. Também podem ser visualizados enquanto representação simbólica dos traços culturais e identitários da comunidade santacruzana. Um traço marcante pode ser percebido na manutenção dessa tradição, desde as suas primeiras edições no século XVIII, possibilitando aos seus participantes momentos de devoção e integração social dos envolvidos nos festejos e em suas celebrações.

Em relação aos festejos e celebrações do Divino Espírito Santo, percebemos que em diversos momentos das celebrações ocorreram mudanças, outras vezes fundiram outras práticas culturais nesta festividade, mas, é inegável o devotamento dos fiéis, o carinho e o rigor com que tratam dos preparativos e como os representam nos momentos festivos. Embora tenham sofrido algumas mudanças, tornara-se uma tradição que tem se perpetuado em seus diversos aspectos.

Dois motivos primordiais se apresentam para essa preservação cultural: Primeiramente, por ser essa festa um legado ibérico dos conquistadores e dos primeiros povoadores de Santa Cruz de Goiás, os luso-brasileiros que em se estabelecendo por ali deixaram um legado imenso, seus usos e costumes, sua arte, sua religião, sua língua, e seu folclore. Num segundo momento, constatamos o caráter sagrado dos festejos por meio da divulgação da devoção católica. O elemento sagrado trouxe adesão coletiva. Trazendo a população local, os demais que migraram para outras cidades e turistas da região. Esses, por sua vez, participam aliando esses dois elementos, que são a tradição festiva e a devoção católica.

Concluímos que os festejos trazem à tona, brechas capazes de desconstruir o atual estado das coisas, de transformar e revitalizar a vida social de um povo. Entretanto, não se trata de rompimento de conflitos pela coesão social. Não podemos afirmar que as procissões católicas reforçam a ordem de uma sociedade. Mas que amenizam, quando se unem grupos de vários seguimentos no propósito da devoção do Divino, pelas bênçãos recebidas: a vida, a mesa farta, o pão de cada dia, a saúde dos entes queridos, os laços afetivos, dentre outros. No entanto, o que é mais evidente é a aliança e o forte vínculo dos festejos como ato de devoção. 
Desse modo, considera-se que a Festa do Divino Espírito Santo faz parte da história e da cultura dessa região, com diferentes significações. São festejos que envolvem eventos, personagens, detalhes, sons e cores diversas, o que permitem a sociedade criar e recriar suas próprias manifestações, sua própria cultura.

\section{REFERÊNCIAS BIBLIOGRÁFICA}

ALVES, J. R. (1983): As Cavalhadas de Santa Cruz de Goiás. Santa Cruz de Goiás-GO: Prefeitura Municipal de Santa Cruz de Goiás.

BONETTI, M. C. de F. (2004): Contra-Dança: Ritual e Festa de Um Povo. Dissertação de Mestrado em Ciência da Religião, Universidade Católica de Goiás. Departamento de Filosofia e Teologia, Goiânia.

BOURDIEU, P. (2001): O Poder Simbólico. Rio de Janeiro: Bertrand Brasil.

BRANDÃO, A. P. (2008): Dicionário Memória das Palavras. Goiânia: Funarte.

BRANDÃO, C. R. (1976): O divino, o santo e a senhora. Rio de Janeiro: Funarte.

D'ABADIA, M. I. (2014). Diversidade e Identidade Religiosa: uma leitura espacial dos padroeiros e seus festejos em Muquém, Abadiânia e Trindade - GO. Jundiaí-SP: Paco Editorial.

DEL PRIORE, M. L. (2000): Festas e utopias no Brasil colonial. São Paulo: Brasiliense.

DIAS, R. (2006): Turismo e Patrimônio Cultural - recursos que acompanham o crescimento das idades. São Paulo: Saraiva.

GARCIA, RWD. (Orgs). (2005): Antropologia e Nutrição: um diálogo possível. [Online] Rio de Janeiro: FIOCRUZ. <http://books.Scielo.org>

GEERTZ, C. O beliscão do destino: a religião como experiência, sentido, identidade e poder. En GEERTZ, C. (2001): Luz sobre a antropologia. Rio de Janeiro: Zahar. pp. 149-165.

GINZBURG, C. (1991): A Micro-História e outros ensaios. Lisboa: DIFEL.

SILVA, M. M.; DEUS, M. do S. (2002): História das Festas e Religiosidades em Goiás. Goiânia: Agepel/UEG.

\section{BIOGRAFIA DOS AUTORES}

Liberalina Teodoro de Rezende. Professora do Departamento de História da Universidade Estadual de Goiás

Sandro Dutra e Silva. Professor Titular do Centro Universitário de Anápolis e da Universidade Estadual de Goiás

Giovana Galvão Tavares. Professor do Programa de Pós-Graduação em Sociedade, Tecnologia e Meio Ambiente do Centro Universitário de Anápolis - UniEVANGELICA

Maria Idelma Vieira D’abadia. Professor do Programa de Pós-Graduação em Territórios e Expressões Culturais do Cerrado da Universidade Estadual de Goiás

Abadia de Lourdes da Cunha. Professora da Secretaria de Educação do Estado de Goiás.

Ámbitos. Revista Internacional de Comunicación, n.31, edición de invierno, 2016. 
Recibido: 26/03/2015

Aprobado: 25/04/2015 